TOWARD COMPETITION IN LOCAL TELEPHONY

William J. Baumol and

J. Gregory Sidak

Local telephone companies have long been extensively regulated as natural monopolies. Technological innovation and the prospect for lifting regulatory barriers to entry, however, now expose at least some portions of the local exchange to competition from cable television systems, wireless telephony, and rival wireline systems.

William Baumol and Gregory Sidak examine how telecommunications regulation can be designed to adapt automatically as the market becomes increasingly competitive. If certain parts of local telephony remain naturally monopolistic, how can regulators protect consumers against cross-subsidy, predatory pricing, and price discrimination? How should a local exchange carrier that is a natural monopoly in some activities be permitted to price necessary inputs it sells to its competitors in the market for the final telecommunications products?

AEl Studies in Telecommunications

Deregulation.

Copublished with the AEI Press

176 pp. $\quad \$ 27.50$ (March)

\section{THE MIT ENCYCLOPEDIA OF} THE JAPANESE ECONOMY

Robert C. Hsu

From "Administrative guidance" (gyosei shido) to the "Zenshinren Bank," this encyclopedic dictionary defines basic concepts and terms from the Japanese economy. The only work of its kind in English, it is a convenient and comprehensive guide to all important economic and business aspects of dynamic postwar Japan.

460 pp. $\quad \$ 45.00$ (May)
THE BUSINESS ENTERPRISE IN JAPAN Views of Leading Japanese Economists edited by Kenichi Imai and Ryutaro Komiya translation edited and introduced by Ronald Dore and Hugh Whittaker

Is capitalism everywhere driven by the same logic of market forces, contract, and individualistic motivation? Or is Japan different? These eighteen contributions by leading Japanese economists shed light on a number of issues in this increasingly important debate.

The variety of perspectives and the range of firms covered - not only the large industrial corporation but cooperatives, public enterprises, and mutual life insurance companies as well provide a broad overview that few other books on Japanese business can offer.

320 pp., 23 illus. $\$ 35.00$ (July)

Second Edition Now in Paperback

MARKETS OR

GOVERNMENTS

Choosing between Imperfect Attematives Second Edition

Charles Wolf, Jr.

Reviews of the first edition:

"Exceptionally well written...I would strongly recommend this book to any student of comparative economic organization."

- Oliver E. Williamson, Journal of Economic Literature

256 pp. $\$ 14.95$ paper
The MIT Press

55 Hayward Street

Cambridge, MA 02142 


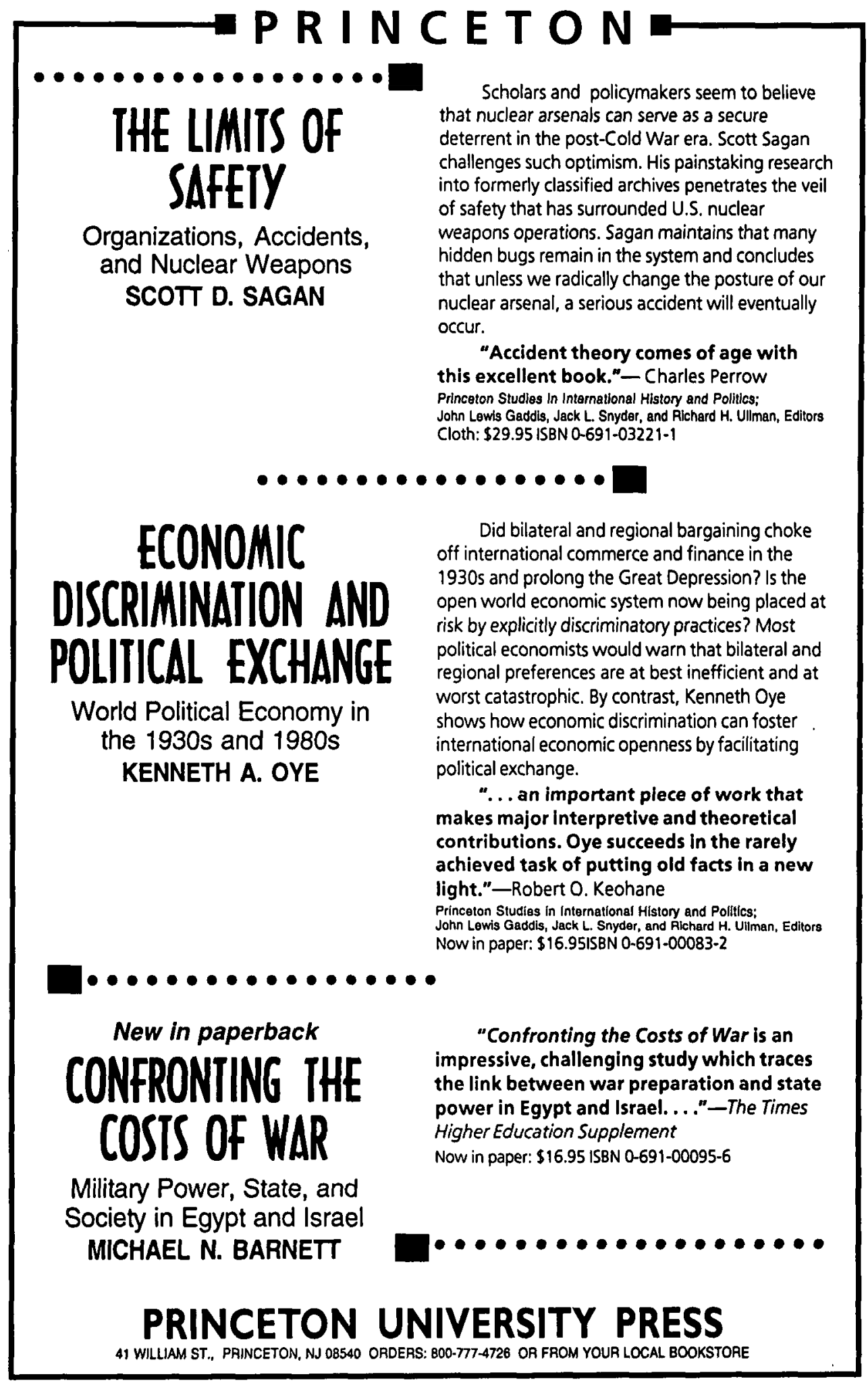




\section{International Organization $_{\text {rat }}$ Back Issues}

\section{Featured Articles}

Vol. 33, No. 1, Winter 1979 The Political Consequences of the Product Cycle: Industrial History and Political Outcomes James R. Kurth

Vol. 33, No. 3, Summer 1979 The Management of Surplus Capacity: Or How Does Theory Stand Up to Pro-tectionism 1970s Style?

Susan Strange

Vol. 33, No. 4, Autumn 1979 An Economic Theory of Mutually Advantageous Issue Linkages in International Negotiations Robert D. Tollison, Thomas D. Willett

Vol. 34, No. 1, Winter 1980 Towards a Marxist Theory of European Integration Peter Cocks

Vol. 34, No. 2, Spring 1980 Self-Reliance in Theory and Practice in Tanzanian Trade Relations Thomas J. Biersteker

Vol. 35, No. 2, Spring 1981 Sphere of Flying: The Politics of International Aviation ChristerJonsson

Vol. 35, Na 3, Summer 1981 Third World Indebted Industrialization: International Finance and State Capitalism in Mexico, Brazil. Algeria, and South Korea Jeff Frieden

Vol. 35, No. 4, Autumn 1981 The GATT and the Regulation of Trade Barriers: Regime Dynamics and $F$ unctions Jock A. Finlayson, Mark W.Zacher

Vol. 36, No. 1, Winter 1982 The Political Economy of Indian Joint Industrial Ventures Abroad Dennis J. Encamation

Vol. 36, No. 3, Summer 1982 Managing the Global Commons PerMagnus Wijkman
Vol. 36, No. 4, Autumn 1982 Capitalism and Hegemony: Yorubaland and the International Economy David D. Laitin

Vol. 37, No. 1, Winter 1983

Hegemonic Stability Theory and Nineteenth-Century Tariff Levels in Europe Timothy J. McKeown

Vol. 37, No. 4, Autumn 1983 The Unraveling of the Multi-Fiber Arrangement, 1981: An Examination of International Regime Change Vinod $\mathrm{K}$. Aggarwal

Vol. 38, No. 1, Winter 1984 Breaking with Orthodoxy: The Politics of Economic Policy Responses to the Depression of the 1930s Peter Alexis Gourevitch

Vol. 38, No. 2, Spring 1984 The Hegemon's Dilemma: Great Britain, the United States, and the International Economic Order Arthur A. Stein

Vol. 38, No. 3, Summer 1984 Policy Coordination by Major Western Powers in Bargaining with the Third World: Debt Relief and the Common Fund Barbara B. Crane

Vol. 38, No. 4, Autumn 1984 Economic Structure and International Security: The Limits of the Liberal Case Barry Buzan

Vol. 39, No. 1, Winter 1985 The Empire Strikes Back: The Transformation of the Eastern Bloc from a Soviet Asset to a Soviet Liability Valerie Bunce

\section{Vol. 39, No. 4, Autumn 1985}

The Limits of Hegemonic Stability

Theory Duncan Snidal

Vol. 40, No. 1, Winter 1986 Neomercantilism and International Economic Stability Paolo Guerrieri, PierCarto Padoan
Vol. 40, No. 3, Summer 1986 International Human Rights: $A$ Regime Analysis Jack Donnelly What Is Nationalism and Why Should We Study It? Emst B. Haas

Vol. 41, No. 1, Winter 1987 Crisis Prevention and the Austrian State Treaty

Deborah WelchLarson

Vol. 41, No. 3, Summer 1987 Nordic Economic Policies in the 1970s and 1980s Lars Mjøset

Vol. 41, No. 4, Autumn 1987 Quasi-States, Dual Regimes, and Neoclassical Theory: International Jurisprudence and the Third World Robert $\mathrm{H}$. Jackson

Vol. 42, No. 2, Spring 1988 NATO and the Persian Gulf: Examining Intra-alliance Behavior Charles A. Kupchan

Vol. 43, No. 1, WInter 1989 The Impact of Ideas on Trade Policy: The Origins of U.S. Agricultural and Manufacturing Policies Judith Goldstein

Vol. 44, Na. 3, Summer 1990 Multilateral Negotiations: $A$ Spatial Analysis of the Arab. Israeli Dispute Bruce Bueno de Mesquita

Vol. 44, No. 4, Autumn 1990

How Japan Affects the International System Henrik Schmiegelow and Michèle Schmiegelow

Vol. 45, No. 2, Spring.1991 The East European Countries and GATT: The Role of Realism, Mercantilism, and Regime Theory in Explaining East-West Trade Negotiations Leah Haus

Vol. 45, No. 3, Summer 1991 Political Leadership and Regime Formation: On the Development of Institutions in International Society Oran R. Young 
Vol. 46, Na. 1, Winter 1992 SPECIAL ISSUE: Rnowledge, Power, and Internationl Policy Coordination Edited by Peter M. Hass

Vol. 46, No. 3, Summer 1992 Symposium: Multilateralism with John Gerard Ruggie, James A. Caporaso, Steve Weber, Miles Kahler

Vol. 46, No. 4, Autumn 1992 Managing Domestic Differences in International Negotiations: The Strategic Use of Internal Side-Payments Frederick W. Mayer

From Competition to

Collaboration: The Challenge of Commercial-class Aircraft Mantfacturing Vicki L Golich
Vol. 47, No. 1, Winter 1993 Choosing Union: Monetary Politics and Maastricht Wayne Sandholtz Domestic Reform and International Change: The Gorbachev Reforms in Historical Perspective Valerie Bunce

Vol. 47, No. 2, Spring 1993

The International Labor

Organization and the Welfare

State: Institutional Effects on

National Welfare Spending, 1960 -

80 David Strang and Patricia Mei

Yin Chang

Macropolitical Consensus and

Lateral Autonomy in Industrial

Policy: The Nuclear Sector in

Brazil and Argentina Etel

Solingen
Vol. 47, No. 3, Summer 1993 Side-payments versus Security Cards: Domestic Bargaining

Tactics in International

Economic Negotiations $\mathrm{H}$.

RichardFriman

Human Rights, Principled Issuenetworks, and Sovereignty in Latin America Kathryn Sikkink Territoriality and Who is "US"? Ethan Kapstein, John Gerard Ruggie

\section{International $\mathbf{O}_{\text {rganization }}$}

Please send me the following back issue(s):

$$
\begin{aligned}
& \text { - } 3311-364 \text { - } 40.3 \text {-461 } \\
& \text { - }^{37: 3} \text { 37:1 }^{37: 1}{ }^{40: 3} \\
& \text { - 37:4 - 37:4 - 41:3-16:4 } \\
& { }^{34: 1}{ }^{30: 1} \text { - }^{41: 4}{ }^{47: 1} \\
& -{ }^{342}-{ }^{34: 2}-0.2-472 \\
& \text { - 35:2 }{ }^{38: 3} \text { - }^{4: 1} \text { - } 4: 3 \\
& -35.3-384{ }^{343} \\
& \text { - 35:4 - 39:1 - } \\
& \text { - 361 - } 39.4-4 \times 2 \\
& -^{36 \times 3}-0.1-4 \times 3
\end{aligned}
$$

1 am ordering

copy (coples) at:

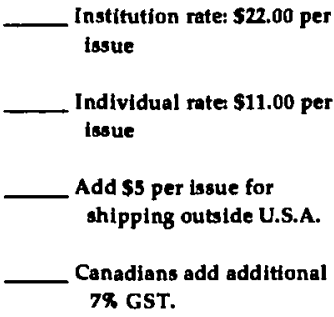

TOTAL
Prepayment is required. Send check or money order-drawn on a U.S. bank in U.S. funds, payable to International Organization- MasterCard or VISA number to:

Circulation Department MIT PRESS JOURNALS 35 HAYWARD STREET CAMBRIDGE, MA 02142-1399 USA

TEL: (617) 253-2889

PAX: (617) 258-6779

journals-ordersemitedu

_Chexk of money orter-drawn on a U.S. bank in U.S. funds, paybita to International Organization-is enciosed.

Charge to my _ MnsterCard _ VISA Account No.

Expiration Date

Slgnature/Today's Date

Print candhoider's nume

Send to (please print cleartyh

Name

Company/Depaztment

Address

City/State/Province/ZIP/Country

Daytme phone Glit from 


\section{International Security}

". . . easily the most

important and

consistently interesting

journal in the field ..."

John Lewis Gaddis,

Steven E. Miller, Editor

Published quarterly
by The MIT Pros
for she Center for
Science and
Intemasional Affairs,
Harvard University.

"By providing rigorous, theoreticallyinformed scholarship on crucial security issues, is consistently advances the scholarly analysis of infernational relations and sets the terms of debate on confemporary policy problems." Stephen Walt, University of Chicago

\begin{abstract}
A Security provides lucid, well-documented essays on all aspects of the control and use of force, from all political viewpoints. Its articles cover contemporary policy issues, and probe historical and theoretical questions behind them. Whether a topic is emerging, maturing or taking an interesting twist, each issue of IS provides important information, penetrating analysis, or new interpretation. Recent important articles include:
\end{abstract}

\section{"Russia's Foreign Policy.Alternatives" -Alexei G. Arbatov}

"The Emerging Structure of International Politics" -Kenneth N. Waltz

"The Unipolar Illusion: Why New Great Powers Will Rise" -Christopher Layne

"International Primacy: Is the Game Worth the Candle?"

$$
\text { -Robert Jervis }
$$

"Why International Primacy Matrers"

- Samuel P. Huntington

"International Relations: Theory and the End of the Cold

$$
\begin{gathered}
\text { War" } \\
\text {-Jobn Lewis Gaddis }
\end{gathered}
$$

Subscribe to International Security and be at the hub of national and international political and security debates.

Yearly rates: Individual \$32; Institution \$85; Student and Retired \$20. Subscriptions outside U.S.A. add $\$ 14$ postage and handling. Canadians also add 7\% GST. Prepayment is required. Send check, MasterCard or VISA number to: MIT Press Journals 55 Hayward Street Cambridge, MA 02142-1399 TEL 617/253-2889 FAX 617/258-6779 joumals-orders@mit.edu

ISSN 0162-2889 


\section{DOUBLE-}

"Shows how an integrative analysis of domestic and international politics can aid understanding of many bilateral negotiations. This suggestive volume is likely to affect research on international negotiations for years to come." -Robert $\mathrm{O}$.

Studies in International Political Economy, $\$ 50.00$ cloth, $\$ 17.00$ paper Keohane, Harvard UNIVERSITY OF CALIFORNIA PRESS University 


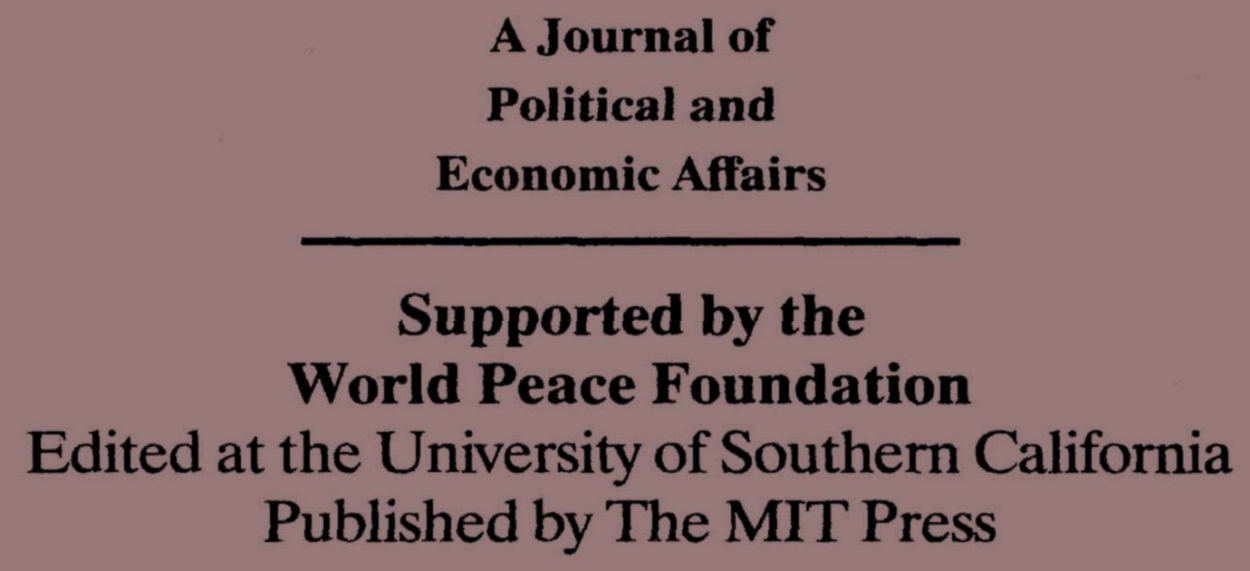

Political and

Economic Affairs

Supported by the

World Peace Foundation

Published by The MIT Press 